University of Nebraska - Lincoln

DigitalCommons@University of Nebraska - Lincoln

$10-2000$

\title{
Correlations Between Burrowing Owl and Black-Tailed Prairie Dog Declines: A 7-Year Analysis
}

\author{
Martha J. Desmond \\ New Mexico State University \\ Julie A. Savidge \\ Colorado State University - Fort Collins, julie.savidge@colostate.edu \\ Kent M. Eskridge \\ University of Nebraska-Lincoln, keskridge1@unl.edu
}

Follow this and additional works at: https://digitalcommons.unl.edu/natrespapers

Part of the Natural Resources and Conservation Commons

Desmond, Martha J.; Savidge, Julie A.; and Eskridge, Kent M., "Correlations Between Burrowing Owl and Black-Tailed Prairie Dog Declines: A 7-Year Analysis" (2000). Papers in Natural Resources. 162.

https://digitalcommons.unl.edu/natrespapers/162

This Article is brought to you for free and open access by the Natural Resources, School of at DigitalCommons@University of Nebraska - Lincoln. It has been accepted for inclusion in Papers in Natural Resources by an authorized administrator of DigitalCommons@University of Nebraska - Lincoln. 


\title{
Correlations Between Burrowing Owl and Black- Tailed Prairie Dog Declines: A 7-Year Analysis
}

\author{
Martha J. Desmond, ${ }^{1}$ School of Natural Resource Sciences, University of Nebraska-Lincoln, Lincoln, NE 68583 \\ Julie A. Savidge, ${ }^{2}$ School of Natural Resource Sciences, University of Nebraska-Lincoln, Lincoln, NE 68583 \\ Kent M. Eskridge, Department of Biometry, University of Nebraska-Lincoln, Lincoln, NE 68583
}

1 Present address - Department of Fishery and Wildlife Sciences, New Mexico State University, Las Cruces, NM 88003 2 Present address - Department of Fishery and Wildlife Biology, Colorado State University, Fort Collins, CO 80523

\begin{abstract}
Concern over the status of species associated with prairie dog colonies has increased with the recent proposed listing of black-tailed prairie dogs (Cynomys ludovicianus). We monitored burrowing owl (Athene cunicularia) populations and prairie dog densities in 17 black-tailed prairie dog colonies in the Nebraska panhandle between 1990 and 1996. All prairie dog colonies were controlled at least once during the study. We observed a $63 \%$ decline in nesting pairs of burrowing owls and significant declines in burrow densities. Results indicated a time lag in owl response to changes in active burrow densities. However, in the later years of the study when burrow densities were lowest, owl numbers were positively correlated with the density of active burrows in the same years, indicating active burrows may become more important as burrow density declines. We also monitored fledging success of burrowing owls for 398 nesting attempts over 5 years (1989-93) for a larger set of colonies that included the 17 used in the owl and prairie dog monitoring. Differences in mean fledging success among colonies each year (colony effect) explained most of the variation in fledging success among nesting owls. Vulnerability to badger (Taxidea taxus) predation may in part explain differences in fledging success among colonies; badger predation on owl nests was lower when densities of active prairie dog burrows were high. Efforts are needed to ensure preservation of black-tailed prairie dog colonies for burrowing owls and other species associated with this prairie ecosystem, and to better monitor changes in burrowing owl and prairie dog populations.
\end{abstract}

Keywords: Athene cunicularia, Speotyto cunicularia, black-tailed prairie dog, burrowing owl, Cynomys ludovicianus, fledging success, Great Plains, Nebraska, North American badger, prairie dog control, predation, Taxidea taxus

Burrowing owls are strongly associated with colonial sciurids in the Great Plains and are most commonly found nesting in burrows in black-tailed prairie dog colonies (Butts 1973, Desmond 1991). Black-tailed prairie dogs are highly colonial (Hoogland 1995) and historically covered tens of millions of hectares (Anderson et al. 1986). However, agriculture, sylvatic plague (Yersinia pestis), and control programs reduced black-tailed prairie dog populations by an estimated 90-98\% since 1900 (Summers and Linder 1978, Anderson et al. 1986, Miller et al. 1994). In response to the nationwide decline in prairie dog populations, the National Wildlife Federation recently petitioned the U.S. Fish and Wildlife Service to list the black-tailed prairie dog as a threatened species (Graber et al. 1998). Although the petition was denied, U.S. Fish and Wildlife Service concluded listing was warranted but precluded due to other listing priorities (National Wildlife Federation 2000). Although several studies have explored the as- sociation of burrowing owls with black-tailed prairie dog colonies (Butts 1973, MacCracken et al. 1985, Plumpton 1992, Hughes 1993, Pezzolesi 1994), little is known of the importance of prairie dogs to burrowing owls other than the fact that their burrows serve as nesting locations. The only available information on longterm trends for burrowing owls is the Breeding Bird Survey, which is of questionable value for monitoring raptor populations (Holroyd and Wellicome 1997). Burrowing owls are considered endangered in Canada and a species of special concern in many western and midwestern states in the United States (Sheffield 1997).

During the early stages of a study on burrowing owl ecology (Desmond 1991), we observed widespread efforts to control prairie dogs in western Nebraska. In Nebraska, $98 \%$ of the land is privately owned, and until 1995, Nebraska state law required that prairie dogs on private and public property be annually eradicated. Nebraska's reports of 7,636 and 6,516 ha 
of black-tailed prairie dog colonies controlled in 1990 and 1991, respectively (U.S. Department of Agriculture 1990, 1991), accounts for over half of the reported prairie dog control activity nationwide in those years (13,218 ha in 1990 and 11,000 ha in 1991; Roemer and Forrest 1996). Because of the strong dependence of owls on burrows, we predicted that reduction of prairie dogs would lead to declines in burrowing owls. We monitored burrowing owls and prairie dog burrows (as a relative measure of prairie dog density) for 7 years. Thus, the first objective of this paper was to report on the observed population trends. Other studies have found that owls selected nesting areas with greater burrow densities (Plumpton 1992) and a higher percentage of active prairie dog burrows (Hughes 1993). We therefore predicted that owl numbers within a colony would be positively correlated with densities of active prairie dog burrows. Additionally, since many bird species show some degree of philopatry and return to the same breeding grounds in subsequent years (Greenwood 1987), we predicted that owl numbers might show a time lag in response to changes in active burrow densities.

A second objective was to evaluate the association between fledging success of burrowing owls and prairie dog numbers. Owls nesting in burrows within an active colony may benefit by early predator detection due to prairie dog alarm calls or by the dilution effect (increased safety from predation due to the abundance of alternative prey, prairie dogs, in the same area). Additionally, burrowing owls select for areas with reduced grass coverage and height (Butts and Lewis 1982, Green and Anthony 1989, Plumpton 1992), possibly allowing for increased predator and prey detection (Green and Anthony 1989). Through their intense grazing and clipping of vegetation, prairie dogs may help maintain conditions suitable for burrowing owls. Thus, we predicted that active burrow densities would be positively related to fledging success. We also predicted that inactive burrow densities would reflect intensity of prairie dog control and would be negatively related to fledging success. Owls will nest in clusters within prairie dog colonies and may benefit from increased predator detection by other owls (Desmond et al. 1995). Thus, we predicted that fledging success would be positively related to owl numbers. Our third objective was to examine the relationship between predation on owl nests by the North American badger and prairie dog densities. Badgers are the main predator of the burrowing owl in western North America (Green and Anthony 1989, Desmond 1991). In white-tailed prairie dog (C. leucurus) colonies, female badgers spent more time foraging in colonies than expected based on habitat distribution (Goodrich and Buskirk 1998). If burrowing owls benefit from prairie dog presence (alarm calls, the dilution effect, or reduced vegetation height), rates of badger predation on burrowing owl nests should be negatively associated with prairie dog density.

\section{Study Area}

Our research was conducted in Banner, Box Butte, Morrill, Scotts Bluff, and Sioux counties of the Nebraska Panhandle during the spring and summers of 1990-96. Vegetation was characteristic of mixed- and short-grass prairie; dominant species included buffalo grass $(\mathrm{Bu}$ chloe dactyloides), blue grama (Bouteloua gracilis), needleandthread grass (Stipa comata), western wheatgrass (Agropyron smithii), crested wheatgrass (Agropyron cristatum), downy brome (Bromus tectorum), fringed sage (Artemisia frigida), and sand sage (Artemisia frilifolia; Desmond 1991). Soils on the prairie dog colonies were variable, but consisted primarily of loamy fine sand or fine sandy loam (Soil Conservation Service $1968,1983,1985,1996)$. Study sites were individual prairie dog colonies. Some sites were remnants of native grasslands in an agricultural matrix while other sites were in open rangelands. Prairie dog colony size was $48.9 \pm 14.7$ ha $(\bar{x} \pm \mathrm{SE}$, range $=0.2-300)$. With one exception, all study sites were located on private land. Cattle grazed all sites on private land, and prairie dogs were controlled at least once on each site during our study. Cattle grazing was uniform within sites across years; however, prairie dog control was not. Some sites were heavily controlled and prairie dog populations eradicated. Other sites were controlled repeatedly throughout this study. Two methods of prairie dog control were used on our study sites: burrow fumigants, which resulted in the immediate loss of burrows, and above ground poison bait.

\section{Methods}

We initially located prairie dog colonies using aerial photographs and by contacting local landowners. Entire colonies were thoroughly 
and repeatedly searched for burrowing owl nests in May of each year by walking line transects through the colony such that the entire colony was transversed. We believe we located all nesting pairs.

Prairie dog control was difficult to quantify on our study sites due to different levels of expertise among individuals applying control, and due to differences in effort, season of application, and method of control. We therefore felt that measures of active and inactive prairie dog burrows were the best indicator of intensity of prairie dog control. During 1990 and 1992-96, we counted active and inactive prairie dog burrows within 10 random, rectangular transects $(4 \times 100 \mathrm{~m})$ in each of 17 prairie dog colonies. In 1991, we used circular plots to census burrows, and thus, these counts could not be directly compared with the other 6 years. We used active burrows as a relative measure of prairie dog activity (Biggins et al. 1993). To obtain a more accurate index, we modified the criteria of Biggins et al. (1993) for accessing active and inactive prairie dog burrow densities. Visual sighting of a prairie dog, fresh scat (blackish-green in color), or fresh digging indicated an active burrow. We considered a burrow inactive if it met 2 or more of the following criteria: presence of unclipped vegetation in the burrow entrance or on the mound, burrow entrance heavily covered with spider webs, or absence of fresh prairie dog fecal pellets (D. E. Biggins [U.S.G.S. Biological Resources Division] and S. E. Hygnstrom [University of Nebraska], personal communication). We counted all burrows in which the entrance was at least halfway within the transect.

We collected data on fledging success for 398 burrowing owl nests found between 1989 and 1993. In addition to the 17 colonies used for the long-term monitoring of owl numbers, we included an additional 9 colonies to increase our sample size for evaluating reproduction. The additional 9 colonies were not included in the longterm monitoring (1990-1996) because it was not feasible to access them in all years. Not all colonies had nesting owls each year. We defined fledging success as the number of young per nest that survived to 42 days of age (Haug 1985). We monitored nests on a weekly basis for owl activity and behavior, and nests were only approached if the owls did not seem to be present or the nest appeared lost to predation. We calculated numbers of owls within a $250-\mathrm{m}$ radius of each nest burrow and measured the distance to the nearest nest. We used the number of owls within a 250-m radius of each nest as an index of owl numbers because owls nesting in clusters within prairie dog colonies were never greater than $250 \mathrm{~m}$ apart. We also believed this was the maximum distance at which owls were able to vocally and behaviorally communicate. For statistical analysis of nearest-neighbor distance for single nests within prairie dog colonies, we added $50 \mathrm{~m}$ to the largest nearest-neighbor distance recorded within a prairie dog colony that year. Thus, solitary nests had the largest nearestneighbor distances, indicating they were more isolated than others. Since the density of active burrows immediately surrounding a nest may influence reproductive success, we counted all burrows within a 75-m radius of each nest in 1991 and 1992, and classified them as active or inactive using the criteria described above.

During 1990-92, we measured badger predation on burrowing owl nests being monitored for fledging success. Badgers leave a characteristic fan-shaped mound at the burrow entrance (Green and Anthony 1989, Desmond 1991). We monitored badger predation for the 6-week period following nest initiation, the time when most badger predation occurred and the entire brood was at greater risk (Desmond 1991). This included a 4-week incubation period and the 2week period during which nestlings remained in their natal burrow. Predation on nests during this 6-week period resulted in the loss of the eggs or entire brood, and often the incubating female. Once chicks dispersed to satellite burrows around the nest burrow, badger predation rates could not be determined. We focused on badger predation because it was easy to identify, and badgers are the main predator of burrowing owls in the Great Plains. It is very difficult to identify other sources of predation due to the underground location of the nest.

We evaluated trends over years in burrowing owl numbers per colony and mean density of active and inactive prairie dog burrows by fitting orthogonal polynomial growth curves to the across-year repeated measures of the prairie dog colonies (Morrison 1976, Wilkinson 1992). Since we could not use burrow data from 1991, we used unequally spaced orthogonal polynomials to analyze the burrow data. We tested for linear, quadratic, and cubic trends in owl numbers and burrow densities over time using a multivariate repeated measures approach, which does not 
need special covariance structure (i.e. sphericity) or adjustments in degrees of freedom as required with univariate repeated measures approaches. We used Pearson correlations to examine relations between number of burrowing owls per colony and mean density of active burrows per colony within the same year, and the relation between number of owls per colony and mean density of active burrows per colony from all previous years to test for a time lag in owl response to changes in active burrow density.

We used regression analysis to examine the relation between fledging success of individual nests and independent variables: owl numbers within $250 \mathrm{~m}$ of an individual nest, distance to the nearest neighboring burrowing owl nest, and additionally in 1991 and 1992, active and inactive prairie dog burrow densities within 75 $\mathrm{m}$ of the nest. Colony was used as a classification variable in the model by designating a categorical variable that represented each colony; all nests within the same colony were grouped by the same number. This was done to evaluate variation in fledging success due to factors at the level of the prairie dog colony rather than the individual nest. Prior to regression analysis, we examined independent variables for collinearity using simple correlations on all pairs. All variables had Pearson correlation coefficients 0.7 , our cutoff, and thus, were retained in the regression analysis. Fledging success was normalized using a $\ln +1$ transformation. To analyze badger predation on owl nests during 1990-92, prairie dog colonies were divided into 2 density categories based on clear breaks in the data sets observed on histograms. Classifications ranged from 0 to 6.5 burrows $/ 400 \mathrm{~m}^{2}$ for low density colonies and 8.5 to 11.2 burrows $/ 400 \mathrm{~m}^{2}$ in high density colonies. For each year we cross-classified nests by badger predation (+ or - ) and density of active burrows. We then used these categories in a Fisher's exact test on the $2 \times 2$ table for each year to determine if the probability of badger predation on owl nests was lower in high density prairie dog colonies than in low density colonies (Steel and Torrie 1980). We evaluated differences in badger predation rates between high and low density prairie dog colonies among years by testing prairie dog density $\times$ year interaction using a weighted-least squares categorical response model. To reduce distributional and computational problems associated with zero cells, a value of 0.5 was added to each cell (Agresti 1990).

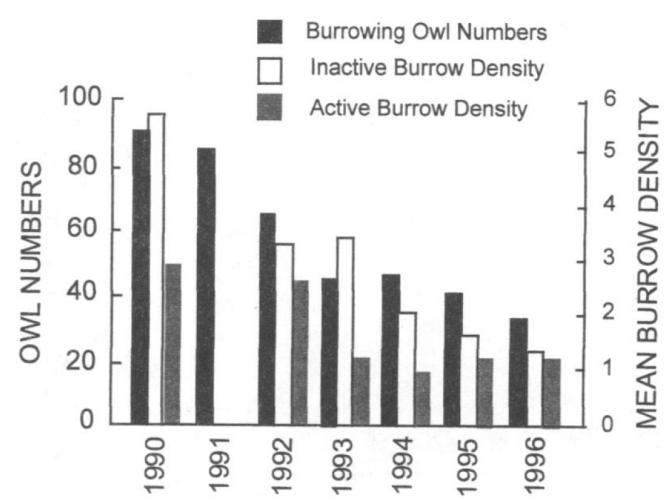

Figure 1. Changes between 1990 and 96 in the number of burrowing owls and mean numbers of active and inactive burrows $/ 400 \mathrm{~m}^{2}$ for the 17 prairie dog colonies in Nebraska. Burrow density data collected in 1991 were not used due to different census techniques.

\section{Results}

Nesting pairs of burrowing owls declined $63 \%$ over the 7 -year period in the 17 prairie dog colonies, from 91 nests in 1990 to 34 nests in 1996 (Figure 1). We did not observe unpaired owls using these colonies. Owl numbers decreased linearly across years $\left(F_{1,16}=6.46, P=\right.$ 0.022 ). Density of active and inactive prairie dog burrows for 1990 and 1992-96 declined linearly across time $\left(F_{1,16}=4.78, P=0.04 ; F_{1,16}=61.40, P\right.$ $<0.001$; respectively; Figure 1).

Number of burrowing owls in 1992-96 was positively correlated with mean density of active burrows per colony in 1990 and 1991 (Table 1). Number of owls in 1995 was positively correlated with mean density of active burrows in 1995, and numbers of owls in 1996 was positively correlated with mean density of active burrows in both 1995 and 1996 (Table 1).

From 1989 to 1993, the number of fledglings per nest averaged $1.9 \pm 0.1$. We observed a significant colony effect on fledging success in all 5 years $(P \leq 0.02$, Table 2$)$. In 1989 and 1990, none of the within-colony variables measured were related to fledging success. In 1991 both the number of owls within a $250-\mathrm{m}$ radius of owl nests and the number of inactive burrows within a 75-m radius of owl nests were positively related to fledging success. In 1992, active prairie dog burrow density was positively associated with fledging success. None of the within colony variables measured were related to fledging success in 1993. 
Table 1. Pearson correlation matrix of number of burrowing owls and mean density of active burrows for 17 prairie dog colonies in Nebraska during 1990-96.

\begin{tabular}{|c|c|c|c|c|c|c|c|}
\hline \multirow{2}{*}{$\begin{array}{l}\text { Mean density } \\
\text { of active } \\
\text { burrows/colony }\end{array}$} & \multirow[b]{2}{*}{1990} & \multicolumn{4}{|c|}{ Burrowing owl numbers/colony } & \multirow[b]{2}{*}{1995} & \multirow[b]{2}{*}{1996} \\
\hline & & 1991 & 1992 & 1993 & 1994 & & \\
\hline 1990 & 0.335 & $0.481^{*}$ & $0.623^{* *}$ & $0.797^{* * *}$ & $0.512^{*}$ & $0.608^{* *}$ & $0.537^{*}$ \\
\hline 1991 & & 0.306 & $0.501^{*}$ & $0.539 *$ & $0.561^{*}$ & $0.615^{* *}$ & $0.533^{*}$ \\
\hline 1992 & & & 0.136 & 0.224 & 0.441 & 0.121 & 0.036 \\
\hline 1993 & & & & 0.343 & 0.366 & 0.185 & 0.105 \\
\hline 1994 & & & & & 0.421 & 0.360 & 0.270 \\
\hline 1995 & & & & & & $0.653^{* *}$ & $0.585^{*}$ \\
\hline 1996 & & & & & & & $0.552^{*}$ \\
\hline
\end{tabular}

*P $\leq 0.05 ;{ }^{* *} P \leq 0.01 ; * * * P \leq 0.001$

Table 2. Regression coefficients for fledging success vs. independent variables collected for owl nests within prairie dog colonies in Nebraska (1989-93). Density of active and inactive burrows was determined only in 1991 and 1992.

\begin{tabular}{|c|c|c|c|c|c|}
\hline Variables measured & $\begin{array}{c}1989 \\
n=70^{\mathrm{a}}\left(14^{\mathrm{b}}\right)\end{array}$ & $\begin{array}{c}1990 \\
n=97(15)\end{array}$ & $\begin{array}{c}1991 \\
n=89(14)\end{array}$ & $\begin{array}{c}1992 \\
n=80(16)\end{array}$ & $\begin{array}{c}1993 \\
n=62(17)\end{array}$ \\
\hline Owl numbers & 0.000 & -0.002 & $0.002^{* c}$ & 0.000 & 0.000 \\
\hline Nearest-neighbor & 0.005 & -0.048 & 0.095 & -0.002 & 0.033 \\
\hline Active burrow density & & & 0.003 & $0.013^{*}$ & \\
\hline Inactive burrow density & & & $0.167^{*}$ & -0.007 & \\
\hline \multicolumn{6}{|l|}{ Colony effect ${ }^{\mathrm{d}}$} \\
\hline 1 & 1.679 & 1.842 & -1.038 & 0.011 & -1.871 \\
\hline 2 & 1.582 & 0.441 & & -0.254 & -0.982 \\
\hline 3 & 1.749 & 1.960 & 0.523 & 0.492 & 0.000 \\
\hline 4 & 0.846 & 1.779 & -0.634 & 0.997 & -1.698 \\
\hline 5 & 1.247 & 1.762 & -0.506 & & -1.725 \\
\hline 6 & 0.733 & 0.534 & -0.081 & -0.057 & -1.882 \\
\hline 7 & 0.006 & & -0.801 & & -1.212 \\
\hline 8 & 0.051 & 2.426 & -0.525 & & \\
\hline 9 & 1.437 & & & & \\
\hline 10 & 0.847 & 0.480 & 1.094 & -0.678 & -0.957 \\
\hline 11 & 1.150 & & -0.841 & -0.422 & \\
\hline 12 & 0.212 & & & & \\
\hline 13 & 0.007 & & 1.220 & 1.109 & -0.960 \\
\hline 14 & 1.437 & & & & \\
\hline 15 & & 1.207 & -1.161 & 0.256 & -1.927 \\
\hline 16 & & 2.036 & -0.016 & 0.368 & -1.809 \\
\hline 17 & & 1.593 & -0.891 & & \\
\hline 18 & & 0.326 & -0.410 & & -1.374 \\
\hline 19 & & 0.284 & & 1.005 & -1.877 \\
\hline 20 & & 2.426 & & & \\
\hline 21 & & & & 0.386 & -1.343 \\
\hline 22 & & & & 1.168 & -1.882 \\
\hline 23 & & & & 0.137 & \\
\hline 24 & & & & 0.418 & \\
\hline 25 & & & & -0.343 & \\
\hline 26 & & & & & 0.713 \\
\hline Model $r^{2}$ & 0.49 & 0.45 & 0.56 & 0.59 & 0.54 \\
\hline
\end{tabular}

a Number of nests monitored for fledging success.

${ }^{\mathrm{b}}$ Number of colonies with nesting owls.

c Significance $(*)$ was based on $P \leq 0.05$.

${ }^{\mathrm{d}}$ Colony was significant for each year $(P \leq 0.02)$. Blanks indicate either data were not collected or owls were not present at that site that year. 
Table 3. Badger predation on burrowing owl nests in low and high density prairie in Nebraska dog colonies (1990-92).

\begin{tabular}{|c|c|c|c|c|c|c|}
\hline \multirow[b]{2}{*}{ Year } & \multirow{2}{*}{$\begin{array}{l}\text { Prairie dog } \\
\text { density }\end{array}$} & \multicolumn{2}{|c|}{ Nests predated } & \multicolumn{2}{|c|}{ Nests not predated } & \multirow[b]{2}{*}{$P^{a}$} \\
\hline & & $n$ & $\%$ & $n$ & $\%$ & \\
\hline \multirow[t]{2}{*}{1990} & Low & 6 & 16 & 31 & 84 & 0.008 \\
\hline & High & 0 & 0 & 33 & 100 & \\
\hline \multirow[t]{2}{*}{1991} & Low & 27 & 48 & 29 & 52 & 0.004 \\
\hline & High & 4 & 16 & 21 & 84 & \\
\hline \multirow[t]{2}{*}{1992} & Low & 16 & 42 & 22 & 58 & 0.019 \\
\hline & High & 0 & 0 & 11 & 100 & \\
\hline
\end{tabular}

a $P$-values from Fisher's Exact Test for $H_{0}$ : probability of predation in high density colonies is no greater than low density colonies.

The probability of badger predation of burrowing owl nests was significantly lower when nests were in high density colonies than in low density colonies in $1990(P<0.008), 1991$ ( $P<$ $0.004)$, and $1992(P<0.019$; Table 3$)$. There was no significant difference across years in rates of badger predation in high and low density prairie dog colonies $(P>0.05)$.

\section{Discussion}

The number of burrowing owls and prairie dog burrows declined substantially throughout the 7-year period. It is possible that owls on our study sites moved to other suitable habitat, but prairie dog colonies within the Great Plains, especially the central and southern plains, are limited (Mulhern and Knowles 1995). In general, both active and inactive burrows declined over time, but burrow densities began to increase in some colonies in later years. Soil texture has a significant effect on burrow longevity; burrows in sandy soils, such as on our study area, fill more rapidly than those in loamy soils (Green and Anthony 1989). Besides rapid degradation of burrows in sandy soil, fumigation was a prevalent control technique and resulted in immediate loss of burrows. Butts and Lewis (1982) found that prairie dog burrows in Oklahoma were gone within 3 years following control.

The positive correlations observed between burrowing owl numbers later in the study and active prairie dog burrow densities in the earlier years may be related to a time lag in owl response to changes in prairie dog densities. Over the years, we observed that owls reused not only the same prairie dog colonies, but the same cluster areas, the same territorial boundaries within the cluster, and often the identical nest burrows as the previous year (Desmond 1991). We do not know if the same owls returned to our sites; however, philopatry is thought to be common in most birds (Greenwood 1987). If burrowing owls in western Nebraska return to traditional nesting grounds, particularly sites where they bred successfully the previous year, return rates the following year would not necessarily be influenced by changes in habitat quality (Van Horne 1983). In fact, one would predict owl numbers to be unchanged the year after prairie dog control and would then subsequently decline as nests became more vulnerable to predation and birds either dispersed or died. We observed this pattern among nesting owls on several of the prairie dog colonies in this study. Positive correlations, mainly in the later years of the study, between owl numbers and active burrow densities in the same year indicated that active burrows may become important to owls once burrows decline to a certain threshold level.

Burrowing owls may benefit from the presence of prairie dogs in the vicinity of nests since the density of active prairie dog burrows was positively related to fledging success in 1 of the 2 years examined. Successful nests (fledging $\geq$ 1 juveniles) had an average of 96 active prairie dog burrows within a $75-\mathrm{m}$ radius of the nest, whereas unsuccessful nests had an average of 26 (Desmond and Savidge 1999). Badger predation of burrowing owl nests also was lower in high-density prairie dog colonies, possibly contributing to the differences in fledging success among colonies. Hoogland (1981) found the rate of predator detection for black-tailed prairie dogs was a function of the number of individuals present. Prairie dogs may benefit burrowing owls through their alarm calls, by serving as an alternative prey source for badgers and other predators (dilution effect), or by reducing vegetation height and allowing increased visibility of 
predators. Additionally, burrowing owls often use several burrows within prairie dog colonies (Desmond and Savidge 1999); this is especially important for prefledged chicks. By distributing a brood among burrows, owls may be less likely to loose the entire brood to predation.

Inactive burrows were positively related to fledging success in one of the years, contrary to our prediction. However, density of active and inactive burrows was positively correlated in that year (Pearson correlation $=0.25, P=0.018$ ), suggesting that inactive burrows were not necessarily indicative of control efforts.

Owl numbers were positively related to fledging success during 1 of the 5 years. Burrowing owls nested in clusters in large prairie dog colonies (>35 ha), and within clusters they were territorial, maintaining a mean internest distance of $125 \mathrm{~m}$ (Desmond and Savidge 1996). Burrowing owl numbers also were positively related to the size of prairie dog colonies (Desmond and Savidge 1996). Thus, sufficient habitat for numerous nesting pairs is important whether they benefit from the presence of other nesting owls or some other factor provided by large colonies. Other studies of colonial nesting species have reported reduced rates of predation with increased colony size (Nisbet 1975, Hoogland and Sherman 1976, Fuchs 1977, Hoogland 1981).

We observed a strong colony effect on fledging success within each of the 5 years. This indicated that much of the variation influencing fledging success was not at the nest level, but rather at the scale of the prairie dog colony. Besides differences in vulnerability to predation, other possible factors at the colony scale include the importance of traditional nesting grounds and site familiarity, vulnerability to flooding, prairie dog colony size and shape, topography, soil type, or prey base. Burrowing owls forage both on and off of prairie dog colonies, and other studies have shown active prairie dog colonies supported higher densities of deer mice (Peromyscus maniculatus) and grasshopper mice (Onychomys leucogaster; O'Meilia et al. 1982, Agnew et al. 1986). In fact, it is possible that owls were tracking prey populations that fluctuate with changes in prairie dog densities rather than the prairie dog populations themselves. Important habitats for foraging, and thus prey availability, are difficult to evaluate since these birds are primarily nocturnal hunters. We encourage future research on burrowing owls in prairie dog colo- nies to address these and other issues that have not been adequately studied.

\section{Management Implications}

Burrowing owls are considered a species of special concern in much of their range; however, few long-term studies on population trends have been conducted. Our research indicates owl populations will decline with a concomitant decline in prairie dogs. Additional long-term monitoring is needed in other parts of the owl's range. An experimental approach whereby burrowing owl populations in controlled and non-controlled prairie dog colonies are compared would be valuable.

Factors at the level of the individual prairie dog colony had a significant influence on burrowing owl fledging success. We need a better understanding of potential factors operating at the colony scale such as size, shape, and connectivity of colonies; soils; topography; prey availability for owls, etc. Active prairie dog colonies benefit burrowing owls in several ways. Prairie dogs are likely preferred prey for badgers, so the presence of numerous prairie dogs in a colony should lower the risk of predation on burrowing owl nests. Juvenile owls use numerous satellite burrows within colonies and select for active burrows probably because they are better maintained (Desmond and Savidge 1999). Large prairie dog colonies allow owls to nest in clusters that may promote better predator detection (Desmond et al. 1995). As states throughout the Great Plains begin to develop black-tailed prairie dog conservation plans, there is a need to understand how different conservation strategies will benefit populations of associated species including burrowing owls.

\section{Acknowledgments}

F. E. Andelt, J. J. Dinan, T. E. Labedz, D. R. Virchow, and many Nebraska Ornithological Union members gave us information on burrowing owl nests and prairie dog colony locations. E. M. Lane, M. Mantel, S. J. Penas, J. A. Smith, J. Waterman, and P. Woodruff assisted in the field. Many landowners in the Nebraska panhandle provided hospitality and access to their property. Special thanks to personnel at the Scotts Bluff National Monument for assistance and access to the park property and to the Nebraska U.S. Department of Agriculture Animal and Plant Health Inspection Service Wild- 
life Services office, especially D. E. Williams and J. C. Luchsinger, for access to annual reports. S. E. Hygnstrom, R. J. Johnson, R. S. Lutz, D. Rosenberg, D. E. Williams, and several anonymous reviewers provided helpful comments on the manuscript. Financial support was provided by grants from the University of $\mathrm{Ne}$ braska, Nebraska Game and Parks Commission Nongame Checkoff, The Wildcat Hills Audubon Society, Sigma Xi, and the Center for Great Plains Studies. This is Journal Series 11827 of the Agricultural Research Division, University of Nebraska-Lincoln.

\section{Literature Cited}

Agnew, W., D. W. Uresk, and R. M. Hansen. 1986. Flora and fauna associated with prairie dog colonies and adjacent ungrazed mixed-grass prairie in western South Dakota. Journal of Range Management 39:135-139.

Agresti, A. 1990. Categorical data analysis. Wiley, New York.

Anderson, E., S. C. Forrest, T. W. Clark, and L. Richardson. 1986. Paleobiology, biogeography, and systematics of the black-footed ferret, Mustela nigripes Audubon and Bachman (1851). Great Basin Naturalist Memoirs 8:11-62.

Biggins, D., B. Miller, L. Hanebury, R. Oakleaf, A. Farmer, R. Crete, and A. Dood. 1993. A technique for evaluating black-footed ferret habitat. Pages 73-88 in J. Oldemeyer, D. Biggins, B. Miller, and R. Crete, editors. Management of prairie dog complexes for the reintroduction of the black-footed ferret. U.S. Fish and Wildlife Service Biological Report 93.

Butts, K. O. 1973. Life history and habitat requirements of burrowing owls in western Oklahoma. Thesis, Oklahoma State University, Stillwater, Oklahoma.

, and J. C. Lewis. 1982. The importance of prairie dog colonies to burrowing owls in Oklahoma. Proceedings of the Oklahoma Academy of Sciences 62:46-52.

Desmond, M. J. 1991. Ecological aspects of burrowing owl nesting strategies in the Nebraska panhandle. Thesis, University of Nebraska, Lincoln, Nebraska, USA.

— ing burrowing owl (Speotyto cunicularia) nest densities and numbers in western Nebraska. American Midland Naturalist 136:143-148.

, and, , 1999. Satellite burrow use by burrowing owl chicks and its influence on nest fate. Ecology and conservation of grassland birds of the western hemisphere. Studies in Avian Biology 19:128-130.
_, and T. F. Seibert. 1995. Spatial patterns of burrowing owl (Speotyto cunicularia) nests in black-tailed prairie dog (Cynomys ludovicianus) towns in western Nebraska. Canadian Journal of Zoology 73:1375-1379.

Fuchs, E. 1977. Predation and anti-predator behaviour in a mixed colony of terns, Sterna spp. and blackheaded gulls, Larus ridibundus, with special reference to the sandwich tern, Sterna sandvicensis. Ornis Scandanavia 8:17-32.

Goodrich, J. M., and S. W. Buskirk. 1998. Spacing and ecology of North American badgers (Taxidea taxus) in a prairie-dog (Cynomys leucurus) complex. Journal of Mammalogy 79:171-179.

Graber, K, T. France, and S. Miller. 1998. Petition for rule listing the black-tailed prairie dog (Cynomys ludovicianus) as threatened throughout its range. National Wildlife Federation Home Page: http:// www.nwf.org/nwf/grasslands/petition.html

Green, G. A., and R. G. Anthony. 1989. Nesting success and habitat relationships of burrowing owls in the Columbia Basin, Oregon. Condor 91: 347-354.

Greenwood, P. J. 1987. Inbreeding, philopatry and optimal outbreeding in birds. Pages 207-222 in F. Cooke and P. A. Buckley, editors. Avian Genetics: a population and ecological approach. Academic Press, London.

Haug, E. 1985. Observations on the breeding ecology of burrowing owls in Saskatchewan. Thesis, University of Saskatchewan, Saskatoon, Canada.

Holroyd, G. L., and T. I. Wellicome. 1997. Report on the western burrowing owl (Speotyto cunicularia) conservation workshop. Pages 612-615 in J. R. Duncan, D. H. Johnson, and T. H. Nicholls, editors. Biology and conservation of owls of the northern hemisphere: Second international symposium. U.S. Forest Service General Technical Report NC-190.

Hoogland, J. L. 1981. The evolution of coloniality in white-tailed and black-tailed prairie dogs (Sciuridae: Cynomys leucurus and C. ludovicianus). Ecology 62:252-272.

1995. The black-tailed prairie dog. University of Chicago Press, Chicago, Illinois.

- , and P. W. Sherman. 1976. Advantages and disadvantages of bank swallow (Riparia riparia) coloniality. Ecological Monographs 46:33-58.

Hughes, A. J. 1993. Breeding density and habitat preferences of the burrowing owl in northeastern Colorado. Thesis, Colorado State University, Fort Collins, Colorado.

MacCracken, J. G., D. W. Uresk, and R. M Hansen. 1985. Vegetation and soils of burrowing owl nest sites in Conata Basin, South Dakota. Condor 87:152-154. 
Miller, B., G. Ceballos, and R. Reading. 1994. The prairie dog and biotic diversity. Conservation Biology 8:677-681.

Morrison, D. F. 1976. Multivariate statistical methods. Second edition. McGraw-Hill, New York, New York.

Mulhern, D., and C. J. Knowles. 1995. Black-tailed prairie dog status and future conservation planning. Pages 19-29 in D. W. Uresk, G. L. Schenbeck, and J. T. O'Rourke, technical coordinators. U.S. Forest Service General Technical Report RM-GTR-298.

National Wildlife Federation. 2000. Black-tailed prairie dogs. National Wildlife Federation Home Page: http://www.nwf.org/prairiedogs/dogdecision1.html

Nisbet, I. C. T. 1975. Selective effects of predation in a tern colony. Condor 77:221-226.

O’Meilia, M. E., F. L. Knopf, and J. C. Lewis. 1982. Some consequences of competition between prairie dogs and beef cattle. Journal of Range Management 35:580-585.

Pezzolesi, L. S. 1994. The western burrowing owl: increasing prairie dog abundance, foraging theory, and nest site fidelity. Thesis, Texas Tech University, Lubbock, Texas, USA.

Plumpton, D. L. 1992. Aspects of nest site selection and habitat use by burrowing owls at the Rocky Mountain Arsenal, Colorado. Thesis, Texas Tech University, Lubbock, Texas, USA.

Roemer, D. M., and S. C. Forrest. 1996. Prairie dog poisoning in Northern Great Plains: an analysis of programs and policies. Environmental Management 20:349-359.

Sheffield, S. R. 1997. Current status, distribution, and conservation of the burrowing owl (Speotyto $\mathrm{Cu}$ nicularia) in midwestern and western North
America. Pages 399-407 in J. R. Duncan, D. H. Johnson, and T. H. Nicholls, editors, Biology and conservation of owls of the northern hemisphere: Second international symposium. U. S. Forest Service General Technical Report NC-190.

Soil Conservation Service. 1968. Soil survey of Scotts Bluff County, Nebraska. Soil Conservation Service, Lincoln, Nebraska.

- 1983. Soil survey of Box Butte County, Nebraska. Soil Conservation Service, Lincoln, Nebraska.

- 1985. Soil survey of Morrill County, Nebraska. Soil Conservation Service, Lincoln, Nebraska.

- 1996. Soil survey maps of Sioux County, Nebraska. Soil Conservation Service, Lincoln, Nebraska.

Steel, R. G. D., and J. H. Torrie. 1980. Principles and procedures of statistics. Second edition. McGrawHill, New York.

Summers, C. A., and R. L. Linder. 1978. Food habits of the black-tailed prairie dog in western South Dakota. Journal of Range Management 31: 134-136.

U.S. Department of Agriculture. Animal and Plant Health Inspection Service, Wildlife Services (formerly Animal Damage Control). 1990 and 1991. Annual Reports, State of Nebraska. Lincoln, Nebraska, USA.

Van Horne, B. 1983. Density as a misleading indicator of habitat quality. Journal of Wildlife Management 47:893-901.

Wilkinson, L. 1992. SYSTAT: Statistics, version 5.2 edition. SYSTAT Inc., Evanston, Illinois, USA.

Yost, D. A., D. L Brown, L. L Buller, and J. O. Olson. 1968. Soil survey of Scotts Bluff County, Nebraska. U.S. Government Printing Office, Washington, D.C. 